${ }^{+}$Institut National des langues et des civilisations orientales, Paris; zhang.shuyafr@gmail.com

‡ Centre National de la Recherche Scientifique, Paris; rgyalrongskad@gmail.com

§ Max Planck Institute for the Science of Human History, Jena; khroskyabs@gmail.com

\title{
A study of cognates between Gyalrong languages and Old Chinese
}

\begin{abstract}
Gyalrongic languages, a subgroup of the Burmo-Qiangic branch of the Sino-Tibetan family, are spoken in the Western Sichuan Province of China. They are polysynthetic languages, and present rich verbal morphology. Although they are not closely related to Chinese, they are of particular interest for Sino-Tibetan/Trans-Himalayan comparative linguistics with regards to their conservative phonology and morphology. Based on previous studies on Old Chinese phonology, combining with recent fieldwork data, this paper aims to show how Gyalrong languages could shed light on Old Chinese morphology and thus contribute to the Old Chinese reconstruction. It also proposes a list of possible cognates between Old Chinese, Gyalrong languages, indicating also Tibetan cognates when available.

Keywords: Gyalrong languages, Old Chinese language, etymological cognates, comparative morphology, historical reconstruction.
\end{abstract}

\section{Introduction}

Although Gyalrongic languages are not closely related to Chinese (Sagart et al. 2019), they are of particular interest for Sino-Tibetan/Trans-Himalayan comparative studies since they are the rare languages in the family exhibiting complex consonant clusters (Lai 2017) and conservative morphologies (Jacques 2016b; Gong 2017). However, they have hitherto been neglected by comparativists. This paper aims at providing easily accessible data on potential cognates between Old Chinese (OC) and Gyalrong, and discusses how these comparisons could contribute to improve OC reconstruction.

In section 2, we show how Gyalrong data could shed light on distinction between the anticausative and passive derivations in OC. Section 3 proposes a hypothesis on the origin of OC ${ }^{*}$ - from pre-OC ${ }^{*} s l$ - Section 4 raises some issues concerning medial ${ }^{*} r$ - in current OC reconstructions.

The last section contains a list of possible cognates shared among the Gyalrong languages, Tibetan and the Old Chinese, classified by OC rhymes ${ }^{1}$. The reason for choosing rhymes as the order of classification is justified by the fact that there is some consensus on the rhyme categories of OC, while there are more divergences concerning the consonants. In addition, correspondences are easier to establish between the rhymes of OC and Gyalrongic than between their onsets. Many of the etymologies in this work have been discussed before, in particular those with Tibetan cognates, for which we cite the reference in Schuessler (2007) as a summary of previous scholarship (in particular Conrady 1896; Simon 1929; Coblin 1986; Peiros and Starostin 1996; Gong 1995), and builds on previous comparative research concerning Gyalrong languages (Jacques 2004, 2005).

${ }^{1}$ One of the reviewers has kindly advised to add a long table as data supplement. We agree with this advice, but before making the table accessible as recommended by the reader, it is better to wait until we have data of more languages, in order to provide a more complete database.

Journal of Language Relationship • Вопросы языкового родства • 17/1 (2019) • Pp. 73-92 • ( ) The authors, 2019 
The Gyalrong data come from three varieties, Japhug, Brag-bar (Situ) and Cogtse (Situ). For each cognate, we first list the Chinese word, provided with middle Chinese (MC) and OC reconstructions. We systematically cite Baxter and Sagart's (2014) reconstruction, but in cases when the comparisons are incompatible with their model, we propose alternative possibilities ${ }^{2}$.

\section{Anticausative and passive derivations}

Anticausative $^{3}$ verbs in Gyalrong languages present initial prenasalizing alternations with regards to the basic transitive verbs (Jacques 2008, 84-87; Zhang 2016, 93-95). This process is no longer productive in modern Gyalrong languages. Jacques (2015c) suggests that this prenasalizing element could be etymologically related to the spontaneous-autobenefactive prefix nuin Japhug. While the prenasalizing anticausative has been lexicalized, the spotaneousautobenefactive has undergone regularization and is still highy productive.

As shown in (1), the anticausative verb Brag-bar (Situ) kə-mblèt 'be extinct' (S favān 'bee'), presents initial prenasalizing alternation in regard to the transitive verb Brag-bar (Situ) $k a-p l \bar{\varepsilon} t$ 'to extinguish' (A kact6 $\bar{k} k$ 'leopard', O kałōk 'sheep').

(1) a. Brag-bar (Situ) ka-plēt 'to extinguish'

kactøāk ka kajōk kazēe ta na-plôt.

leopard ERG sheep all DET PFV-to.extinguish ${ }_{\text {II }}$

'The leopard has eaten all the sheep.'

b. Brag-bar (Situ) ka-mblēt 'be extinct'

tsacî javān rgombâ kasâm 'ro-sput rena,

Bkra.shis bee box three IFR.PFV -to.feed ${ }_{I}$ but

u-favān no kazēe no-'ka-mblet

3SG.POSS-bee PL all IFR.PFV-3NS.INTR-be.extinct ${ }_{I}$

'Bkra.shis has fed three beehives of bees, but his bees are all died.'

Note that the direction of derivation should be from a transitive/causative to an intransitive/anticausative verb. This process is not productive in modern Gyalrong languages, however Jacques $(2008,86)$ noticed that in Japhug it is applied to a Tibetan loanword Japhug $\chi$ tor

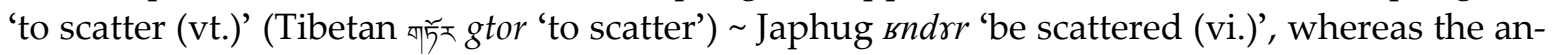
ticausative counterpart does not exist in Tibetan (Jacques 2015c).

Many languages in the ST/TH family have voicing alternations related to transitivity. In Middle Chinese and attested Sinitic languages the prenasalized element has been lost, leaving only initial voicing alternations. Baxter and Sagart (2014) reconstructed a prenasalizing * $N$ prefix to account for this voicing alternations attested in $\mathrm{MC}$, as for instance between 别 pjet < B/S *pret 'to separate' and 别 bjet < B/S *N-pret 'be separated', an example semantically compatible with an interpretation as an anticausative derivation.

However, we also find in OC voicing alternations with meanings that cannot be interpreted as anticausative, such as that between 見 $k e n H<\mathrm{B} / \mathrm{S} *[k]^{\prime}$ en-s 'to see (vt.)' and 現 yenH $<\mathrm{B} / \mathrm{S} * N-[\mathrm{k}]^{\varsigma}$ en-s 'to appear (vi.)'. Anticausative verbs denote spontaneous situations and

2 Since the aim of this study is to illustrate the extent to which Gyalrong languages can contribute to OC reconstruction, we provide some minor amendments to existing reconstruction systems. A full revision of OC historical phonology is beyond the scope of this paper.

3 This argument demoting mechanism derives a intransitive verb from a transitive verb, by suppressing the A of the basic verb and promoting the original O to S (Dixon and Aikhenvald 2000, 315). 
exclude an external cause or agent (Haspelmath 1993), and are thus incompatible with verbs of perception. It is thus difficult to compare the voicing alternation in 現 $y e n H<\mathrm{B} / \mathrm{S} * N-[k]^{\varsigma} e n-S$ with the Gyalrong anticausative.

In Gyalrong languages however, we also find a passive prefix ( $a$ - in Japhug, $o$ - in Bragbar, $y a$ - in Cogtse) originating from a nasal ${ }^{*} y a$-. Example (2) shows the triple contrast between a base transitive verb, its anticausative and its passive in Japhug.

(2) Japhug prrt 'to cut (vt.)'

Japhug mbrrt 'be cut (ANTICAUS, vi.)'

Japhug a-prrt 'be cut (PASS, vi.)'

While a morphological distinction between passive and anticausative seems to be absent in OC, it is possible that the voicing alternation reconstructed as $* N$ - by Baxter and Sagart results in fact from the merger of an anticausative $* N$ - and a passive $* \eta$-derivation (this would not be the only case of merger between etymologically unrelated morphological alternations in OC; the qusheng derivation appears to be a similar case, see Jacques 2016a).

The verbs 敗 $b c e j H$ / 敗 pcejH possibly provide evidence for a contrast between passive and anticausative derivations. The reading brejH with a voiced initial has two distinct meanings 'be damaged' (3) and 'be defeated' (4), whereas that with an unvoiced initial pajH only means 'to defeat' (5).

(3) Anticausative 敗 $b c e j H<\mathrm{B} / \mathrm{S} * N-p^{\top} r a[t]-s$

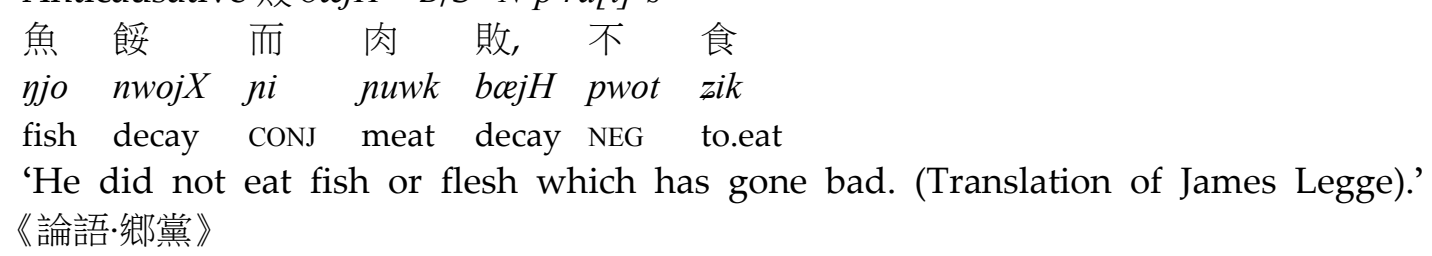

(4) Passive 敗 $b c e j H<\mathrm{B} / \mathrm{S} * N-p^{\uparrow} r a[t]-S$

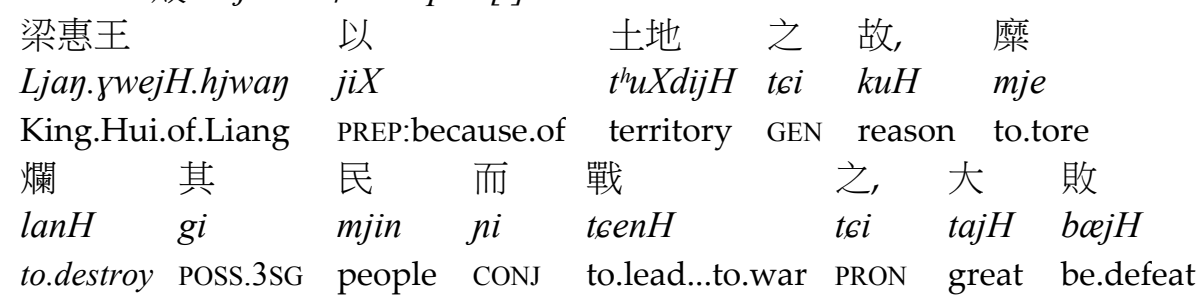

'The king Hui of Liang, for the matter of territory, tore and destroyed his people, leading them to battle. Sustaining a great defeat. (Translation of James Legge)' 《孟子·盡心下》

(5) Transitive 敗 $p c j H<\mathrm{B} / \mathrm{S} * p^{\varphi} r a[t]-S$

冬, 與 越人 水 戰, 大 敗 越人 towy joX hjwotnin 6wij t6enH tajH pajH hjwotnin winter with Yue.people water to.fight great to.defeat Yue.people 'In the winter he had an engagement with that of Yue, on which he inflicted a great defeat. (Translation by James Legge)'《莊子·逍遥遊》

Since the meaning 'be damaged' is necessarily older than 'be defeated' (a semantic change 'defeat' $\rightarrow$ 'destroy' seems highly unlikely), this verb seems to provide evidence for the idea that the intransitive 敗 $b \propto j H$ is the base form, and that the transitive 敗 pajH is derived from it by a causative prefix (as was insightfully pointed out by Wang Hongzhi, pc). 
However, the reasons for not reconstructing a sigmatic causative to account for these voicing alternations have been discussed at length elsewhere (Jacques 2015b; Sagart and Baxter 2012), and it is possible to reconcile OC and Gyalrong data by supposing that 敗 pajH is cognate of Brag-bar (Situ) ka-prāt 'to break', Japhug prrt 'to break', and originally meant 'destroy, damage'. The form 敗 $b c e j H^{*} N$-p $p^{\varphi}$ rats in the meaning 'be damaged' would be an anticausative form of this transitive verb ('become damaged spontaneously, by itself'), itself cognate to Cogtse (Situ) ke-mbrêt 'to break', Brag-bar (Situ) kə-mbrāt 'to break' and Japhug $m b r r t$ 'to break'. The base verb then underwent semantic narrowing to the sense of 'to defeat', from which a passive ${ }^{*} y-p^{\varphi}$ rats (merging early with ${ }^{*} N-p^{\varphi}$ rats, and undistinguishable in MC from the anticausative) was derived.

\section{On the origin of $\mathrm{OC} * \mathrm{l}-$}

Sagart and Baxter (2012) propose a sound change chain concerning consonant clusters consisting of a presyllable ${ }^{*} s($ (a)- and a nasal. Pre-OC tight $s$ - preinitial consonant clusters result in voiceless nasals in OC, whereas loose clusters became tight clusters in $\mathrm{OC}$, as illustrated in (6):

(6) Origin of voiceless nasal in OC (adapted from Table 1 in Sagart and Baxter 2012)

$$
\begin{aligned}
& \text { Pre-OC OC MC } \\
& { }^{*} \mathrm{sm}-,{ }^{*} \mathrm{sn}-,{ }^{*} \mathrm{sn}-\quad>\quad{ }^{*} \mathrm{~m}_{0},{ }^{*} \mathrm{n}_{0}-,{ }^{*} \mathrm{n}^{-} \quad>\quad \chi, \text { th }, \chi \\
& \text { *so.m-, *so.n-, *s.n- > } \quad{ }^{*} \text { sm-, }{ }^{*} \text { sn-, }{ }^{*} \text { sy- } \quad>s
\end{aligned}
$$

In two sets (7), $* l$ - in OC corresponds to the consonant cluster $6 l$ - in Gyalrong languages, suggesting that one of the origins of OC *l- is earlier *sl- (in line with Yakhontov and Starostin 1989, 218).

(7) OC Gyalrong

失 $6 i t<\mathrm{B} / \mathrm{S} *$ li $i t]$ 'to lose' Japhug clur 'toletsth.fall' Cogtse (Situ) ka-flâk 'to fall (from hand)'

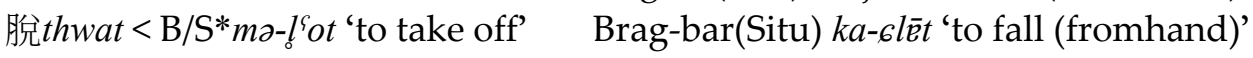

We thus propose ${ }^{*} \operatorname{sli}[t]$ and $s l^{\varsigma}$ ot as pre-OC forms of 失 and 脫.

(8) Origin of OC *l

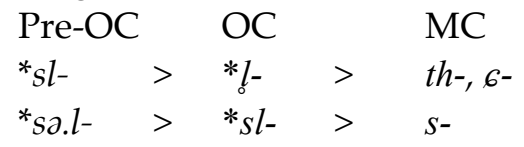

Japhug clmy 'to let sth. fall' is a lexicalized causative of Japhug lmy 'to detach' (the productive causative, expressing a volitional action, is Japhug smyluy 'to cause to detach'), and this is a case where the OC preserves a morphological element as indirect trace only.

\section{4. *-r- medial in OC reconstruction}

The medial *-r - in OC only partially corresponds to medial $-r$ - in languages other than Chinese. In particular, based on comparisons by Gong (1995), Handel (2002) points out that the onsets reconstructed as dental stop or dental affricates+*-r-generally correspond to clusters with preinitial $r$ - in Tibetan, and suggests that metathesis from ${ }^{*} r C$ - to ${ }^{*} C r$ - took place, as summarized in (9): 
(9)

$\begin{array}{lll} & \text { OC } & \text { Non-Chinese languages } \\ \text { Grave } & * C r- & * C r- \\ & * r-C\left(>^{*} C-\right) & * r-C \\ \text { Acute } & * r-C\left({ }^{*} C r-\right) & * r-C \\ *_{s-} & { }^{*} s- & * s r-\text { (before front vowels) } \\ *_{s-} & { }^{*} s- & * s-\text { (before non-front vowels) }\end{array}$

Comparative data from Gyalrong languages could shed light at least on two aspects.

First, the comparison of Japhug tr-zrrm 'root' to 參 B/S *s.rum 'root' shows that Handel (2002)'s hypothesis that ${ }^{*} s r$ - merges with ${ }^{*} s$ - in languages other than Chinese before non-front vowel must be amended (Jacques 2015a).

Second, the grave initial syllables reconstructed with medial $*_{-} r$ - in OC in present reconstructions correspond in some cases to words with preinitial $r$ - in Gyalrong languages (Table 1). We suggest to reconstruct preinitial ${ }^{*} r$ - in these cases in OC. ${ }^{4}$ The difference between preinitial $* r$ - and medial $*$ - $r$ - is not detectable on the basis of Chinese-internal evidence alone, though (depending on the relative chronology of sound changes between Chinese and VietMuong) it is possible that preinitial ${ }^{*} r$ - would yield lenition in old loanwords into Vietnamese (see Pulleyblank 1981, 284 for a suggestion in these lines).

Unlike Handel, we do not think that it is necessary to suppose that metathesis took place in OC - for examples of retroflexion of dental stop by preceding liquids, see Burrow (1972) on Indic languages and Kümmel (2007, 231). Rather, the rhotic (and perhaps other types of preinitials, as suggested by Pulleyblank) became a suprasegmental rhotacized voice quality, as proposed by (Miyake 2012).

Table 1. Preinitial ${ }^{*} r$ - in OC

\begin{tabular}{|c|c|c|c|}
\hline MC & $\mathrm{B} / \mathrm{S}$ & Amended OC & Gyalrong cognates \\
\hline \multirow[t]{3}{*}{ 冰 pin 'ice' } & *p.ray & *rpam & Cogtse (Situ) ta-rpâm 'ice' \\
\hline & & & Brag-bar (Situ) ta-rpâm 'ice' \\
\hline & & & Japhug tr-jprom 'ice' \\
\hline \multirow[t]{3}{*}{ 眉 mij 'eyebrow' } & ${ }^{*} m r[\partial][r]$ & ${ }^{*} r m a j$ & Cogtse (Situ) ta-rnê 'hair', \\
\hline & & & Brag-bar (Situ) ta-rnê 'hair' \\
\hline & & & Japhug tr-rme 'hair' \\
\hline 顏 $\eta æ n$ 'face' & ${ }^{*}$ C. $\eta^{\S} r a r$ & ${ }^{*} r \eta^{\S} a n$ & Japhug tw-rya 'face' \\
\hline
\end{tabular}

There are however a number of unexplained exceptions, such as 謷 yaw $<\mathrm{B} / \mathrm{S}^{*} \eta^{\varsigma} a w$ 'to fry,

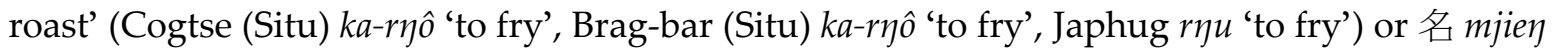
$<\mathrm{B} / \mathrm{S}$ *C.mey 'name' (Cogtse (Situ) ta-rmê 'name', Brag-bar (Situ) ta-rmiê 'name', Japhug tr-rmi 'name') for which no rhotacization can be reconstructed in OC. Note that Tibetan ming शेर' 'name' also lacks a medial or preinitial $r$-.

${ }^{4}$ This hypothesis implies to abandon the reconstruction ${ }^{*} r . \eta^{\varsigma} a$ ? for 魯 $l u X$ proposed to account for a $x i e s h e n g$ relationship with 魚 yjo 'fish'. 


\section{Gyalrong cognates}

\subsection{Open syllable rhymes}

\subsection{1. 鱼 $\mathrm{yu}^{*} a$}

The rhyme 鱼 * $a$ generally corresponds to the vowel $a$ in Cogtse (Situ), ic in Brag-bar (Situ) and $a$ in Japhug. The Brag-bar has undergone the ${ }^{*} a>i \varepsilon$ sound change.

1. 斧 $p j u X<B / S$ * $p(r) a 2$ 'axe', Cogtse (Situ) fa-rpâ 'axe', Brag-bar (Situ) qe-rpiê 'axe', Japhug tu-rpa 'axe'. The first syllable in Situ etyma is the constructed status of the noun Cogtse (Situ) fé 'firewood', Brag-bar (Situ) $q \hat{e}$ 'firewood'. In Japhug, the tu- prefix is the indefinite possessive. The Gyalrongic data suggest the presence of an $r$ - preinitial in Old Chinese (see section 4), but the rime $-j u$ in $M C$ is ambiguous as to the presence or absence of a rhotacizing element.

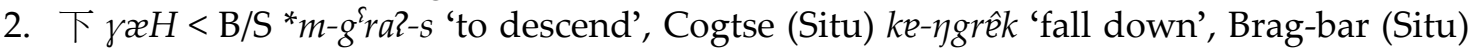

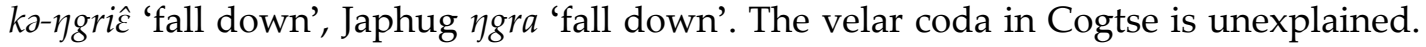
In Gyalrongic languages this verb is the anticausative of the transitive verb (see section 2), reflected by Brag-bar (Situ) ka-kriê 'to cause to fall down', Japhug kra 'to cause to fall down'. An alternative etymology would be 落 lak<B/S * $k$. $r^{\text {f}} a k$ 'to fall' 5 .

3. 蘇 $s u<B / S{ }^{*} s-\eta^{\varsigma} a$ 'to revive'. OC ${ }^{*} s \eta$ - became $s$ - in MC (Baxter 1992, 225; Sagart 1999, 65;

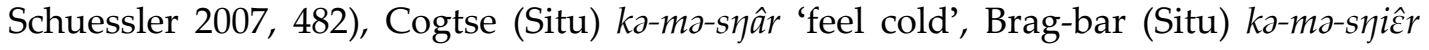
'come to oneself', Japhug sya 'come to oneself'. The Situ forms have a mo- prefix and a $-r$ coda which remain unexplained.

4. 吾 $\eta u<B / S * \eta^{\varsigma} a$ 'I, my', Tibetan $n g a \Sigma^{\prime}$ 'I' (Schuessler 2007, 518), Cogtse (Situ) $\eta \bar{a}$ 'I', Bragbar (Situ) $\eta \bar{a}$ 'I', Japhug $a-\xi o$ 'I'. Northern Gyalrong languages have lost the velar nasal initial $\eta$ - of the singular first person pronouns.

5. 咀 $d z j o X<* d z a$ ? 'to chew', Tibetan $z a-b a$ ə’ব 'to eat' (Schuessler 2007, 323). Cogtse (Situ) $k a-z \bar{a}$ 'to eat', Brag-bar (Situ) $k a-n d z i \hat{\varepsilon}$ 'to eat', Japhug $n d z a$ 'to eat'.

6. 五 $\eta u X<B / S{ }^{*} C . \eta^{\complement} a$ ? 'five', Tibetan lnga 절 'five' (Schuessler 2007, 519). Cogtse (Situ)

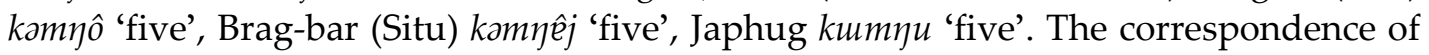
the vowel is irregular. In addition, the correspondence between $l \eta$ - in Tibetan and $m \eta$ in Gyalrong languages is also unexplained (Jacques 2004, 125).

7. 夜 $j x H<B / S *[G] A k-s$ 'night', Tibetan zhag बग 'one night' (Schuessler 2007, 561-62), Brag-bar (Situ) ra-jāk 'one night', Japhug tr-ræzas 'night'. The Brag-bar form takes the numeral prefix ra- 'one'. While this cognate set is not in doubt, the reconstruction of the onset in OC, Tibetan and Gyalrong is problematic. Japhug $r_{7^{-}}$and Situ $f^{-}$could respectively originate from ${ }^{*} r j-$ and ${ }^{*} j-$, and OC might be better reconstructed with a primary yod initial.

\subsection{2. 支 $\mathrm{zhi}^{*} e$}

1. 兒 $n e<\mathrm{B} / \mathrm{S}^{*} \eta e^{\prime}$ 'child'. Jacques $(2004,223)$ relates this word to Japhug $n \gamma-r \eta i$ 'baby', although the first syllable in the Japhug etyma is unexplained. This words could also be related to a lexicalized diminutive suffix in Situ, as in Cogtse (Situ) kho-lyâ 'infant'

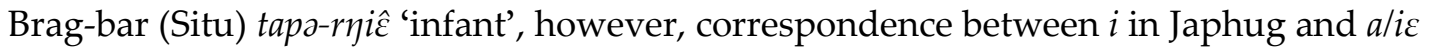
in Situ seems irregular and needs to be further investigated.

${ }^{5}$ Etymology suggested by Laurent Sagart. 


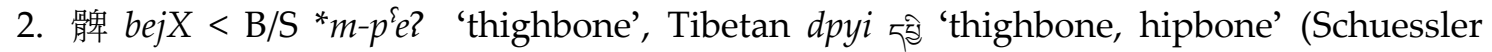
2007, 164), Japhug tu-xpyi 'thigh'.

$$
\text { 5.1.3. 之 } \mathrm{zhi}^{*} \mathrm{\partial}
$$

The rhyme 之 ${ }^{*}$ corresponds to $a$ in Cogtse (Situ), ${ }^{*} a>i \varepsilon$ in Brag-bar (Situ) and $a$ in Japhug.

1. 富 $p j u w H<\mathrm{B} / \mathrm{S}^{*}$ pok-s 'rich'. Sagart (2017) relates this word to Tibetan phag «শ্ 'pig'. If this etymology is accepted, it is also comparable to Cogtse (Situ) pāk 'pig', Brag-bar (Situ) piāk 'pig', Japhug pas 'pig'. Schuessler $(2007,152)$ relates the 'pig' etymon to 犯 pae $<\mathrm{B} / \mathrm{S}^{*} p^{\mathrm{s}} r a$ instead.

2. 子 $t s i X<B / S^{*}[t s] a$ ? 'child'. Schuessler $(2007,633)$ proposes that this word is the ST root for 'offspring, child' and relates it to Tibetan tsha-po ळ'خ্ 'grandchild; nephew'. It could be comparable to Brag-bar (Situ) ta-'tsa-pu 'father's sister's child', Japhug tu-ftsa 'father's sister's child; sister's child' (for the Gyalrong kinship systems and the designation of this word, see Jacques 2012). The Brag-bar etymon is in an incomplete status of noun-compounding since the word is attested with a penultimate accent instead of the final tonal contrast, it can be resulted by a recent suffixation of diminutive - $p u$ (ta-pū 'child') on the base noun *ta-(p)tsa due to changes of its kin terminology. The $p$ - preinitial is preserved in the derived social relation collective Brag-bar (Situ) ko6 $\partial-$ $p t s a-p \hat{a}$ 'paternal cross cousins' daughters'. Correspondence between $p$ - preinitial in Situ and $f$ - preinitial in Japhug is discussed in Jacques $(2004,269-70)$. Another possible cognate of 子 is only shared by Situ dialects, Cogtse (Situ) to-tsâ 'boy, son', Brag-bar

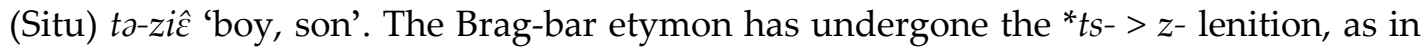
Brag-bar (Situ) *ta-matsa > ta-mazâ 'mother's sister's child'.

3. 装 $g j u w<\mathrm{B} / \mathrm{S}^{*}[g]^{w}$ a 'fur garment', Tibetan gos 爻 'clothes', Cogtse (Situ) to-wê 'garment', Brag-bar (Situ) ta- $\eta g \hat{a}$ 'garment', Japhug $\eta g a$ 'to wear'. The $w$ - initial of the Cogtse etymon can be explained by ${ }^{*} g->w$ - lenition in this dialect. The Tibetan etymon is suffixed by the $-s$ nominalizer.

4. 耳 $n i X<B / S{ }^{*} C . n a$ ? 'ear', Tibetan $r n a$ ₹ 'ear' (Schuessler 2007, 225-26), Cogtse (Situ)

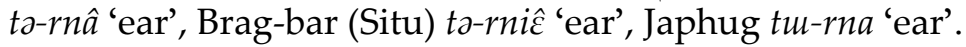

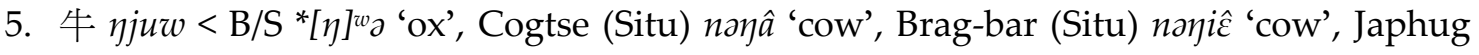
nuүa 'cow'. The first element in the Gyalrong etyma could be related to the con-

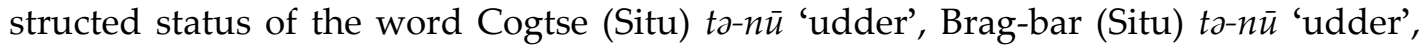
Japhug tu-nu 'udder'. Although most Gyalrong languages have lost the *-w- medial, evidence can be found in Zbu ywé? (Gong 2018, 40).

\subsection{4. 侯 hou ${ }^{*} \mathrm{O}$}

The rhyme ${ }^{*} o$ in OC corresponds to the back vowels in Gyalrong language. It corresponds to $u$ or $u$ in Japhug, and $u$ or $o$ in Situ.

1. 坐 $d z w a X<B / S^{*}[d z]^{5} o[j] 2$ 'to sit', Japhug $a-m d z w$ 'to sit'.

2. 乳 $n u X<\mathrm{B} / \mathrm{S}$ *no? 'milk; nipple', Tibetan nu-ma gु'ঞ 'udder' (Schuessler 2007, 446),

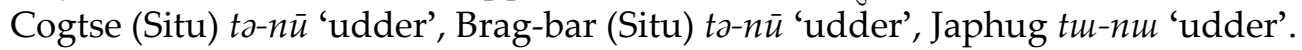

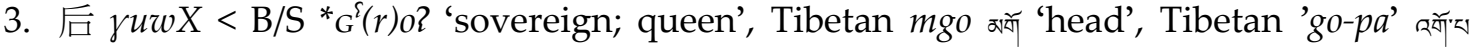
'headman' (Schuessler 2007, 279-80), Cogtse (Situ) ta-kō 'head', Brag-bar (Situ) ta-wô 'head', Japhug $t u-k u$ 'head'. The initial consonant of the Brag-ba etymon has undergone the ${ }^{*} k->w$ - lenition. 
4. 後 $\gamma u w X<\mathrm{B} / \mathrm{S}^{*}[\mathrm{G}]^{\Sigma}(r) o$ ? 'after', Cogtse (Situ) $m \partial-\eta k h \bar{u}$ 'be after', Brag-bar (Situ) mə- $\eta k h \bar{u}$ 'be after', Japhug ma-qhu 'be after'. The Situ and Japhug etyma have a denominal prefix (Jacques 2004, 407).

5. 腑 pjuX < *po? 'internal organs', Cogtse (Situ) to-po-leytfê 'intestine', Brag-bar (Situ) to$v o-$ loyt $\hat{a} \hat{a}$ 'intestine', Japhug tu- $p u$ 'intestine'. The initial consonant of the cognate base in Brag-bar has undergone the ${ }^{*} p$ - $>v$ - lenition.

6. 身區 $k h j u<{ }^{*} k^{h}(r)_{0}$ 'body; person', Tibetan sku 젱 'body, statue' (Schuessler 2007, 435), Cogtse (Situ) tə-skrū 'body', Brag-bar (Situ) tə-skrū 'body', Japhug tu-skhru 'body'.

7. 寇 $k^{h} u w H<\mathrm{B} / \mathrm{S}^{*}[k]^{h \delta}(r)_{0-S}$ 'to rob; robber', Tibetan $r k u-b a$ 䄯 ' to steal' (Schuessler 2007, 336), Brag-bar (Situ) ka-markâ 'bandit', Japhug murku 'to steal'. The Brag-bar form might be loanword from other Gyalrong languages, since it has an unexpected $a$ vowel.

8. 嘔 $2 u w X<B / S{ }^{*} q^{\S}(r) o$ ? 'vomit', Tibetan skyug 죙 'vomit' (Schuessler 2007, 407, 595), Japhug qіов 'vomit'. The final glottal stop ${ }^{*}-2$ possibly corresponds to Tibetan $-g$ and Japhug $-\measuredangle$ (Schuessler 2007, 31-32).

\subsection{5. 幽 you ${ }^{*} u$}

The rhyme 幽 * $u$ correspond to $u$ in Cogtse, $u$ in Brag-bar and $u$ in Japhug.

1. 保 $p a w X<B / S{ }^{*} p^{\varsigma} u$ ? 'to take care of, protect'. In Gyalrong languages we found fixed expressions such as Brag-bar (Situ) $u$-p $\hat{u} k a-v i \hat{\varepsilon}$ 'to take care of', Japhug $u-p u k \gamma-p a$ 'to take care of', consisting of a possessive prefixing action nominal and a light verb Brag-

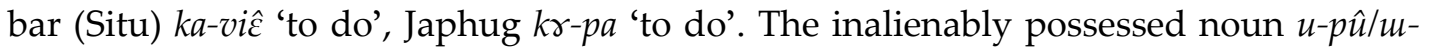
$p u$ in this collocation can be analyzed as an action nominal, as in other non-ambiguous cases Brag-bar (Situ) ta- $\varphi m \hat{o} ~ k a-v i \hat{\varepsilon}$ 'to steal', consisting of the action nominal Brag-bar (Situ) ta-6mô 'stealing' whose corresponding verbal form is Brag-bar (Situ) ka-cmô 'to steal'. Such analysis would suggest the existence of the corresponding verbs Brag-bar (Situ) * $k a-p \hat{u}$ 'to take care of' Japhug ${ }^{*} k \gamma-p u$ 'to take care of' at an earlier stage. An alternative to this light verb construction is a denominal transitive Brag-bar (Situ) $k a-$

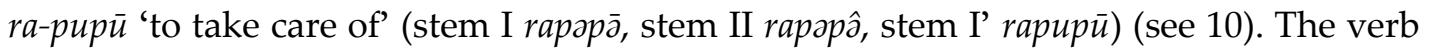
is clearly derived from a nominal base - $p u$, by adding a denominal prefix $r a$ - on the reduplicated base. It is possible that in Gyalrong languages the basic verb 'to take care of' has been lost, whereas the derived action nominal has been preserved and became then the base noun. A similar case is the verb donner 'to give' in French, which does not come from Lat. dare but was recreated from don (< donum 'gift') (List 2016).

2. 浮 $b j u w<\mathrm{B} / \mathrm{S}{ }^{*} m . b(r) u$ 'float' could be indirectly related to Brag-bar (Situ) z̧brū 'boat' and Japhug zmbru 'boat', assuming that these nouns are fossilized sigmatic instrumental nominalizations from a verb *mbru meaning 'float'.

3. 帽 $m a w H<\mathrm{B} / \mathrm{S}^{*} m^{\text {s } u k-S}$ 'hat'. Sagart (2017) relates this word to Tibetan $r m o g$ 珜 'hat, helmet'. The word for 'mushroom' shared in all Gyalrong languages could be possible cognate, Cogtse (Situ) te-jmōk 'mushroom', Brag-bar (Situ) ta-jmōk 'mushroom', Japhug tr-jmry 'mushroom' (Breton tok touseg 'frog hat' for 'mushroom').

4. 腦 nawX $<\mathrm{B} / \mathrm{S}^{*} n^{\varepsilon}[u]$ ' 'brain', Cogtse (Situ) tz-rnōk 'brain', Brag-bar (Situ) ta-rnōk 'brain', Japhug tw-rпов 'brain'.

5. 肘 tjuwX $<\mathrm{B} / \mathrm{S}^{*} t-[k]<r>\mathrm{u}$ ? 'elbow', Tibetan gru-mo 째워 'elbow' (Schuessler 2007, 624), Cogtse (Situ) ta-krū 'elbow', Brag-bar (Situ) ta-krîu 'elbow', Japhug tu-zgru 'elbow'. The $t$ - preinitial in OC could be related to the indefinite possessive prefix $t V$ - in Gyalrong languages. 
6. 爪 $t_{\mathfrak{Q}} æ w X<\mathrm{B} / \mathrm{S}^{*}[t s]^{\wedge}<r>u$ ? 'claw', Cogtse (Situ) ta-ndzrū 'nail', Brag-bar (Situ) ta-ndzrū 'nail', Japhug tu-ndzru 'nail'.

7. 九 kjuwX $<$ B/S *[k]u? 'nine', Tibetan $d g u$ ₹শु 'nine' (Schuessler 2007, 320), Cogtse (Situ)

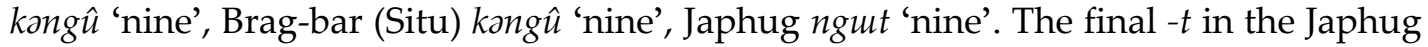
etyma is an innovation in Northern Gyalrong languages; probably due to analogy from Japhug kurcat 'eighy' (Jacques 2004, 253).

8. 舅 gjuwX < B/S * $[g](r) u$ ? 'mother's brother', Tibetan $a-k h u$ ur'/ 'father's brother' (Schuessler 2007, 321), Brag-bar (Situ) $a-k \hat{u}$ 'mother's brother'. The first element in Brag-bar and Tibetan etymon is the vocative prefix. This word is the common SinoTibetan root for mother's brother (Benedict 1942), the Tibetan etyma has undergone a semantic shift from mother's brother to father's brother (Nagano 1994). Correspondence between voiced $g$ - initial in OC and voiceless $k$ - and $k h$ - in Gyalrong and Tibetan etyma could be explained in a similar as (Jacques 2017a) proposes for 父 pjuX $<$ B/S * $[N-p](r) a r$ and Tibetan $p h a \star$ 'father'. ST kin terms are often prefixed either by vocative or by possessive, therefore it is possible that a nasal element is inserted between the possessive/vocative prefix and the root, as the case in Limbu (Davids and Driem 1985).

9. 非 $k j u w X<\mathrm{B} / \mathrm{S}$ *s. [k](r)u? 'allium', Cogtse (Situ) $\int k \bar{o}$ 'onion', Brag-bar (Situ) $q k o \overline{~ ' o n i o n ', ~}$ Japhug $q k u$ 'onion', Tibetan sgog-pa 齐》"v 'wild onion'.

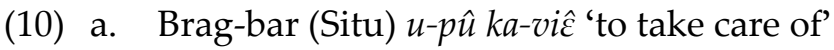

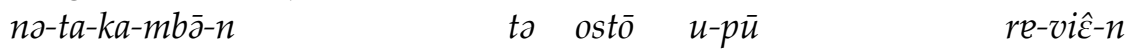

1SG PFV-1 $\rightarrow$ 2-NMLZ-to.give II-2SG DET really 3SG.POSS-protection IMP-to.doI-2SG

'Take care of what I gave to you.'

b. Brag-bar (Situ) ka-ra-pupū 'to take care of'

$n \partial-t a-k a-m b \bar{\partial}-n$ to ostō re-nz-ra-'pəpə-n

1SG PFV-1 $\rightarrow$ 2-NMLZ-to.give ${ }_{\text {II }}$-2SG DET really IMP-AUTO-DENOM-protection ${ }_{\mathrm{I}}$-2SG

'Take care of what I gave to you.'

\section{2. $-k$ ending rhymes}

\subsection{1. 鐸 duo *ak}

The rhyme 鐸 * $a k$ in OC corresponds to $-a k$ in Situ and -ab in Japhug. A few examples correspond to open syllables $a / i \varepsilon$ and $-a$ respectively, a type of correspondence discussed by Sagart (2017).

1. 百 $p x k<\mathrm{B} / \mathrm{S}^{*} p^{\text {`rak }}$ 'hundred', Tibetan brgja 喽 'hundred', Cogtse (Situ) parjâ 'hundred', Brag-bar (Situ) parje 'hundred', Japhug furza 'hundred'. In Brag-bar, ic $<{ }^{*} a$ is realized as $e$ after palatal stops. The initial ${ }^{*} p$ - of the OC etymon corresponds to a presyllable in Gyalrong languages, showing that OC underwent monosyllabicization in this word. The final stop in OC is discussed in Schuessler (2007, 69-70) and Sagart (2017).

2. 膊 phak < * $p^{h \complement} a k$ 'shoulder blade', Tibetan phrag s제 'shoulder' (Schuessler 2007, 170), Cogtse (Situ) to-rpāk 'shoulder', Brag-bar (Situ) ta-rpiāk 'shoulder', Japhug tu-rpas 'shoulder'. Since Tibetan lacks a *rp- cluster, the comparison between Gyalrong and Tibetan suggest that a metathesis ${ }^{*} r p-\rightarrow{ }^{*} p r$ - took place in pre-Tibetan in this etymon.

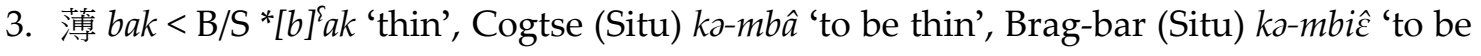
thin', Japhug $m b a$ 'to be thin'. 
4. 莫 $m a k<\mathrm{B} / \mathrm{S}$ * $m^{\S} a k$ 'there is no X such that X ...', Brag-bar (Situ) kə-miāk 'not be', Japhug тав 'not be'. This a common Sino-Tibetan negative copula, it is also related to the negative prefix $m V$ - in Tibeto-Burman languages (Lai 2017, 248). Pulleyblank (2000) (also mentioned by Schuessler 2007, 70) considered the coda $-k$ in ${ }^{*} m^{\varsigma} a k$ to be a distributive suffix ${ }^{*}-k$, and 莫 is derived from 無 ${ }^{*} m a>m j u$ 'not have'. Another example provided by Pulleyblank (2000) is 或 *[G]wร $\partial k>$ fwok 'someone, something', derived from 有 ${ }^{*}[\mathrm{G}]^{w} \mathrm{a}$ ? > hjuwX 'have, exist'. Pulleyblank's hypothesis is not compatible with the comparison presented above.

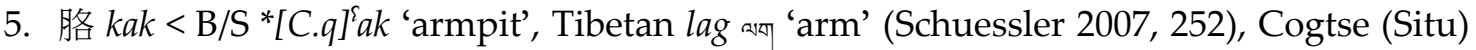
te-jēk 'arm', Brag-bar (Situ) ta-jāk 'arm', Japhug tu-jas 'arm'. This comparison would be more compatible with a reconstruction such as ${ }^{*} k l^{\varsigma} a k$ in OC.

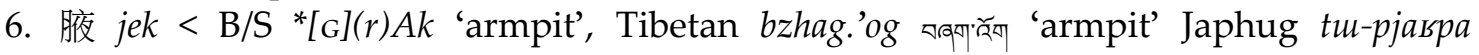
'armpit' (the syllable - pa is a noun meaning 'down, bottom part'). This comparisons suggest eihter a primary yod or a lateral in OC rather than a uvular.

\subsection{2. 錫 $\mathrm{xi}{ }^{*} e k$}

1. 隻 tsjek<B/S *tek 'single', Tibetan gcig गछे 'one' (Schuessler 2007, 614), Cogtse (Situ) kdtēk 'one', Brag-bar (Situ) ka-rīk 'one', Japhug try 'one'. The initial consonant $r$ - of the Brag-bar etymon is due to the ${ }^{*} t->r$ - lenition. A $t$ - initial allomorph can be found in Brag-bar (Situ) zła-tēk 'eleven'.

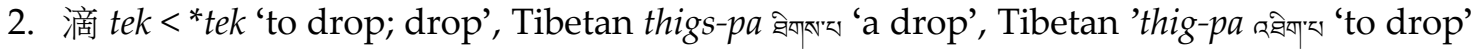
(Schuessler 2007, 209), Cogtse (Situ) nthēk 'drop CLF', Brag-bar (Situ) ra-nthāk 'drop'.

\subsection{3. 職 $\mathrm{zhi}{ }^{*} \partial k$}

A general correspondence between * $z k$ in $\mathrm{OC}$ and $a k$ in Gyalrong languages can be found. The vowel $i \varepsilon<{ }^{*} a$ is realized as $i a C$ before velar codas in Brag-bar.

1. 革 $k \varepsilon k<{ }^{*} k^{\S} r a k$ 'hide' could be compared with Cogtse (Situ) $k a-k l a ̄ k$ 'peel off', Brag-bar (Situ) ka-kliäk 'peel off', under the assumption that the meaning 'hide' derives from 'skin that has been peeled off'.

2. 媐 thok<B/S * $\eta_{0}^{\{} \partial k$ 'evil' Tibetan nag-po 利运 'black' (Schuessler 2007, 493), Cogtse (Situ) kə-nēk 'be black', Brag-bar (Situ) ka-nâk 'be black', Japhug nas 'be black'. The meaning 'evil' is also found in the lexicalized nominal form Japhug $u-\gamma n a s$ 'disastrous consequence', in which the preinitial $\gamma$-is a lenited form of the velar participle prefix.

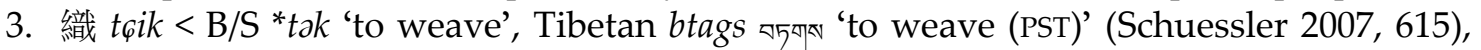
Brag-bar (Situ) ka-tiāk 'to weave', Japhug tas 'to weave'.

4. 色 srik < B/S *s.rok 'color; countenance'. Jacques (2015a) relates this word to Japhug trzras 'shame', despite the semantic gap. Alternative cognates 赤 tshjek $<\mathrm{B} / \mathrm{S}^{*}\left[t-q^{h}\right](r) A k$, 赫 $x æ k<B / S^{*} q^{h s}$ rak 'red' are proposed by Schuessler $(2007,451)$.

\subsection{4. ${ }^{*} i k$}

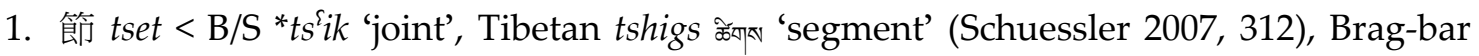
(Situ) $r \partial-r t s \bar{\jmath} k$ 'a segment', Japhug tu-rtsry 'segment'. The first syllable of the Brag-bar etymon is the numeral. It could also be related to Cogtse (Situ) $k a-r a-n t s i \bar{k}$ 'to cut (into segments', Brag-bar (Situ) ka-ra-ntsīk 'to cut (into segments)' (Stem I ra-ntsāk, Stem II ra$n t s \hat{k}$, Stem I' ra-ntsīk, details of stem alternations in Brag-bar see Zhang 2018). 
2. 蟲 sit < B/S *srik 'louse'. *-ik in OC became -it in MC (Baxter and Sagart 2014, 236). Schuessler $(2007,461)$ compares this word to Tibetan shig جेग 'louse'. Japhug zrmy 'louse' is also related. The correspondence between ${ }^{*} s r$ - in OC, Tibetan $\varphi^{-}$and $z r$ - in Japhug is treated in Jacques (2015a).

\subsection{5. 屋 $\mathrm{wu}^{*} \mathrm{ok}$}

1. 曲 khjowk $<\mathrm{B} / \mathrm{S}{ }^{*} k^{h}(r) o k$ 'to bend' and 局 gjowk $<\mathrm{B} / \mathrm{S}{ }^{*} N-k h(r) o k$ 'be bent, curved', Japhug $k r \gamma$ 'to curve' and its anticausative Japhug $\eta g r y$ 'be bent'

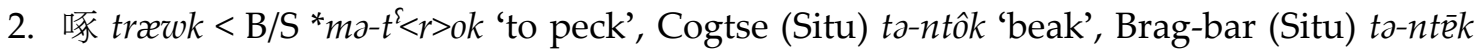
'beak'. The vowel $e$ in the Brag-bar etymon is due to a ${ }^{*}>>e$ sound change. This noun originates from a verb 'to peck' also indirectly attested as a fossilized participle in the compound Cogtse (Situ) fi-kō ka-ntōk 'woodpecker', Brag-bar (Situ) Gewo-'kontek 'woodpecker', which can be regarded as a lexicalized s/A deverbal noun (Sun and Lin 2007; Jacques 2016c).

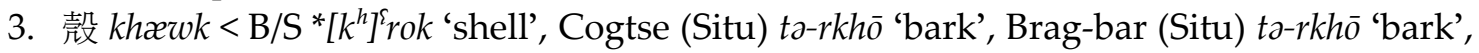

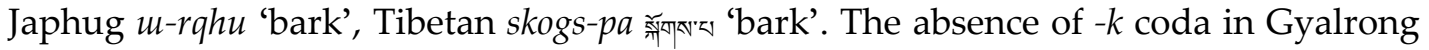
etyma is unexplained.

4. 角 $k æ w k<B / S{ }^{*} C$. $[k]^{\text {' } r o k ~ ' h o r n ' . ~ S c h u e s s l e r ~}(2007,309)$ relates this word to Tibetan $r w a=$ 'horn' (on the rhyme -wa in this word, see Jacques 2009). Cognates are found in Cogtse (Situ) tə-rū 'horn', Brag-bar (Situ) tə-rū 'horn', Japhug ta-sru 'horn'.

\subsection{6. 覺 jue * $u k,{ }^{*} i w k$}

1. 毒 dowk < B/S *[d] $u k$ 'poison', Tibetan $d u g$ รुग 'poison' (Schuessler 2007, 216), Cogtse

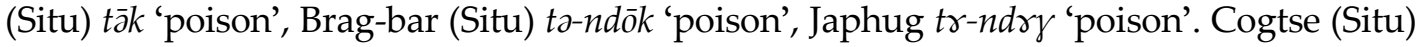
tāk 'poison' is a loanword, otherwise we would expect a voiced initial. Note that in Japhug, the loanword Japhug twy 'poison' (Jacques 2004, 166) coexists with the cognate form Japhug tr-ndry 'poison'.

2. 六 ljuwk< B/S *k.ruk 'six', Tibetan drug 与ुग 'six' (Schuessler 2007, 362), Cogtse (Situ) $k_{\partial}-t_{s} \bar{k} k$ 'six', Brag-bar (Situ) kats̄ok 'six', Japhug kutşry 'six'. The initial consonant tsin Situ and Japhug comes from the Proto-Gyalrong consonant cluster ${ }^{*}$ tr- (Jacques 2004, 294).

3. 腹 $p j u w k<\mathrm{B} / \mathrm{S}^{*} p(r) u k$ 'belly', Tibetan phugs 쩦ㅊ 'innermost part' (Schuessler 2007, 246), Cogtse (Situ) ta-pōk 'belly', Brag-bar (Situ) to-vōk 'belly', Tibetan bug जुञा 'hole'. The Bragbra etymon presents ${ }^{*} p$ - $>v$ - lenition.

4. 目 mjuwk<B/S *C.m(r)[u]k 'eye', Tibetan mig बेषा 'eye' (Schuessler 2007, 392-93), Cogtse (Situ) to-mnāk 'eye', Brag-bar (Situ) tz-mnāk 'eye', Japhug tu-mnas 'eye'. The consonant cluster mp- in Gyalrong etyma comes from * $m j$ - in Proto-Gyalrong (Jacques 2004, 299).

5. 歳 $t$ sjuwk $<{ }^{*} t$ siwwk. The rhyme *iwk is reconstructed for this word given its xiesheng relation 戚 tshek $<\mathrm{B} / \mathrm{S}{ }^{*}$ s.thiiwk. A comparison with Japhug sthos 'to press' would be possible if the sound change ${ }^{*}$ st- $\rightarrow{ }^{*} t$ s- is accepted (Bodman 1969).

\section{3. $-\eta$ ending rhymes}

Gyalrong languages have lost final ${ }^{*} \eta$ in native words, so that cognates with Chinese generally have open syllables corresponding to $\mathrm{OC}^{*}-\eta$. 


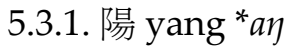

The rhyme 陽 *ay of OC corresponds to - $O$ in Japhug and Situ.

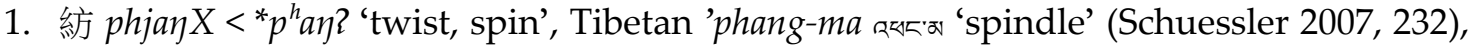
Cogtse (Situ) ka-pô 'to spin', Brag-bar (Situ) ka-pō 'to spin', Japhug pro 'to spin'. The $\gamma$ medial in the Japhug etymon comes from the velarized vowel of Proto-Gyalrong ${ }^{*} p a^{\gamma} \eta$.

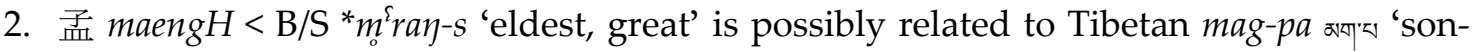
in-law', Cogtse (Situ) to-nmak 'son-in-law', Japhug tr-nmas 'husband'. Another etymology suggested by L. Sagart relates this word with Cogtse (Situ) kə-mbrô 'be tall', Brag-bar (Situ) kz-mbrô 'be tall', Japhug mbro 'be tall'.

3. 攘 $n a \eta X<{ }^{*} n a \eta 2$ 'to oppose; disturb', Cogtse (Situ) ka-nô 'to chase', Brag-bar (Situ) ka-nô

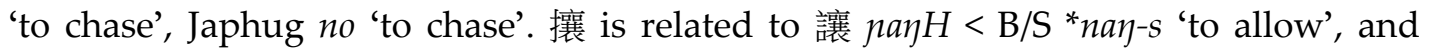
could be possibly related to Tibetan g.nang- $b a$ गाव इ' 'to give, allow'.

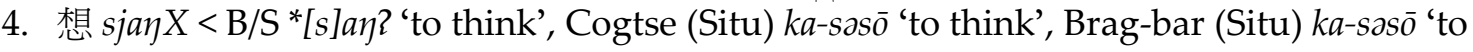
think', Japhug suso 'to think'. The verbs in modern Gyalrong languages are possible reduplicated forms of ${ }^{*}$ say $>{ }^{*}$ so.

5. 剛 $k a \eta<\mathrm{B} / \mathrm{S}{ }^{*} k^{\delta} a \eta$ 'strong, hard', Cogtse (Situ) kə-rkô 'be hard', Japhug rko 'be hard',

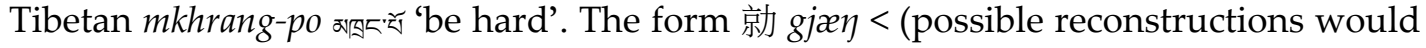
include ${ }^{*}$ gran, ${ }^{*} N-k r a \eta$ or $\left.{ }^{*} N-r k a \eta\right)$ possibly reflects a variant of the same root with a ${ }^{*} r$ like the Gyalrong and Tibetan cognates.

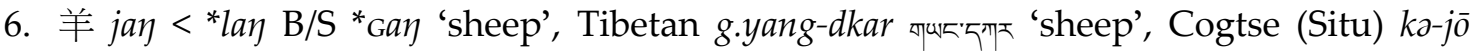
'sheep', Brag-bar (Situ) ka-fōk 'sheep', Japhug qa-zo 'sheep'. The first syllable in Gyalrong date is the prefix designating animals, which could correspond to the $g$ - preinitial in the Tibetan etymon (<PT *Ga-jay, Jacques 2013). The $-k$ coda in the Brag-bar etymon is of unclear origin. Similar phenomenon has also been reported in Kyom-kyo (Situ), in which some words can have two realisations, either with the final velar stop or not,

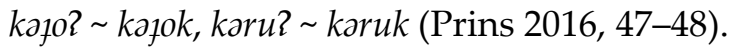

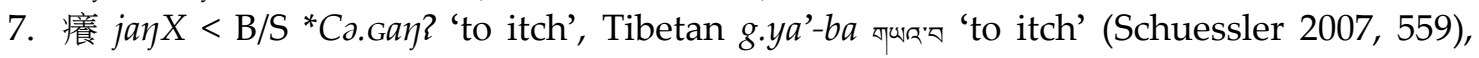
Cogtse (Situ) ka-rajâk 'to itch', Brag-bar (Situ) ka-rejâk 'to itch', Japhug rrła 'to itch'. $r V$ in the Gyalrong etyma could be the denominal prefix. The $-k$ coda in Situ is unexplained. This etymon is better reconstructed with a primary initial yod in OC (Jacques 2013).

\subsection{2. 耕 geng * ${ }^{*} \eta$}

The rhyme 耕 ${ }^{*} e \eta$ in OC corresponds to $e$ in Situ and $i$ in Japhug. A group of ${ }^{*} i{ }^{*} e$ in Brag-bar became $e j$, whose phonetic condition remains to be investigated.

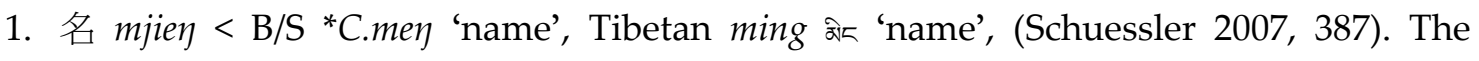
Gyalrong cognates Cogtse (Situ) ta-rmê 'name', Brag-bar (Situ) ta-rmiê 'name', Japhug tr-rmi 'name' have a $r$ - preinitial without equivalent in Chinese and Tibetan.

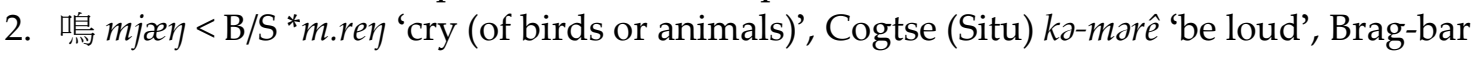
(Situ) ka-mbrêj 'be loud', Japhug mbri 'be loud'. The consonant cluster * $m r$ - in Cogtse became two syllables, with the insertion of $a$, whereas in Brag-bar and Japhug, ${ }^{*} m r->$ mbr- (Jacques 2004, 137).

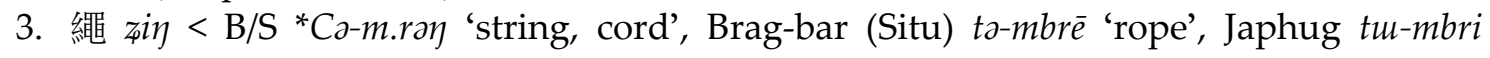
'rope'. 


\subsection{3. 蒸 zheng ${ }^{*} \partial \eta$}

The rhyme 蒸* $\partial \eta$ corresponds to $o$ in Japhug, after merger with *aๆ.

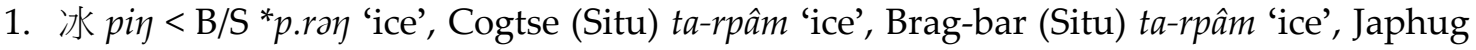
tr-jpyom 'ice', (Schuessler 2007, 168). The $-\gamma$ - medial of the Japhug etymon comes from the velarized vowel ${ }^{*} a^{\gamma}$ in Proto-Gyalrong. The consonant clusters $r p$ - in Situ and $j p$ - in Japhug come from the Proto-Gyalrong ${ }^{*} l p-$. This comparison suggests an alternative reconstruction *rpam with labial dissimilation (see section 4).

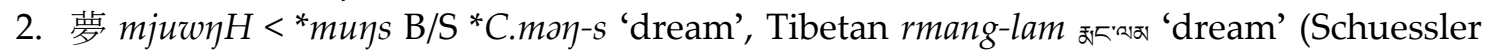
2007, 381), Cogtse (Situ) ta-rmô 'dream', Brag-bar (Situ) ta-rmôk 'dream', Japhug tu-

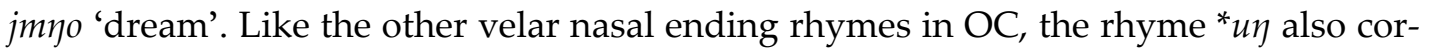
responds to a single vowel in Gyalrong languages. However, the - $k$ coda of the Bragbar etymon is likely to be secondary for two reasons. First, the cognate forms in other Gyalrong languages all end in an open syllable. Second, the denominal verb $k a-v a-r m \bar{o}$ 'to dream' has no coda. The $r$ - preinitial in Situ and $j$ - preinitial in Japhug comes from the ${ }^{*} l$ - preinitial of Proto-Gyalrong $\left({ }^{*} l m->r m\right.$ - in Situ, jm- in Japhug $)$. In addition, the $-\eta$ - medial in Japhug is due to the velarized rhyme ${ }^{*} \operatorname{lm} a^{\gamma} \eta$ in Proto-Gyalrong (Jacques 2004, 44).

3. 乃 $n o j X<\mathrm{B} / \mathrm{S}{ }^{*} n^{\mathrm{r}} \partial(\eta)$ ? 'your', this word is the possessive form of 汝 $n y o X<{ }^{*} n a ?$ 'you (SG)' (Schuessler 2007, 446). It is comparable to Cogtse (Situ) nō 'you', Brag-bar (Situ) $n \partial-\hat{\jmath} \hat{\partial}$ 'you', Japhug $n \gamma-z_{0}$ 'you'. The second element in the Brag-bar and Japhug etyma is the root of the reflexive pronoun taf $\hat{\partial}$ 'oneself' in Brag-bar and $t u-z_{0} 0$ 'oneself' in Japhug. The cognate pronoun in Brag-bar and Japhug etyma might occur in their constructed status.

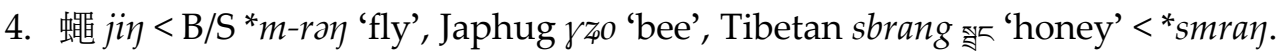

\subsection{4. ${ }^{*}$ iๆ}

The rhyme *iๆ in OC generally corresponds to a single high vowel in Gyalrong languages, $i$ in Japhug and $e$ in Situ.

1. 新 $\sin <\mathrm{B} / \mathrm{S}$ * [s]i[n] 'firewood', Tibetan shing शे 'tree' (Schuessler 2007, 538-39), Cogtse (Situ) $\int \bar{e}$ 'wood, firewood' Brag-bar (Situ) $\varphi \hat{e}$ 'wood, firewood', Japhug si 'wood, firewood'.

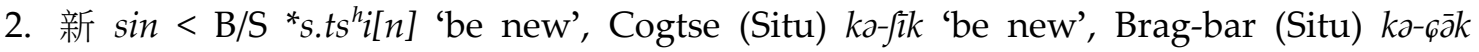
'be new', Japhug $6 r \gamma$ 'be new'. This series is also a case of a non-checked rhyme *i OC corresponding to a checked rhyme in Gyalrong languages.

3. 身 $\operatorname{cin}<\mathrm{B} / \mathrm{S}^{*} n_{0} i[\eta]$ 'body, self', Cogtse (Situ) to-fne 'heart', Brag-bar (Situ) to- $q n \hat{e}$ 'heart', Japhug tu-sni 'heart', Tibetan snying ్ㅗㄷ 'heart'.

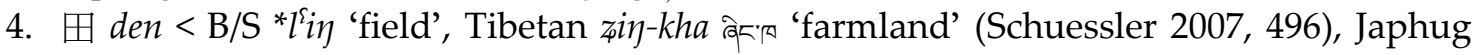
$t u-j i$ 'field'. It is also related to Brag-bar (Situ) ta-jēe 'farming' and Brag-bar (Situ) $k a-j e \hat{e}$ 'to plant', the verb is derived by replacing the nominal prefix to- by the dynamic infinitive prefix $k a-$. Backformation from the noun to the verb is also possible, though less likely.

\subsection{5. 東 dong *o}

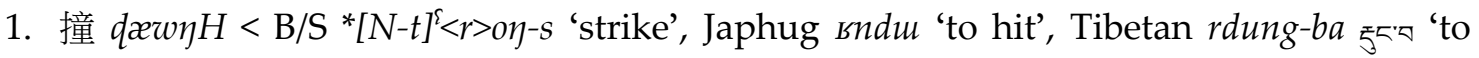
beat'. 


\section{4. - $t$ ending rhymes}

\subsection{1. 月 yue *at}

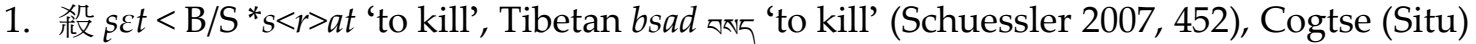
$k a$-sāt 'to kill', Brag-bar (Situ) ka-siēt 'to kill', Japhug sat 'to kill'. For the correspondence between ${ }^{*} s r$ - in OC and $s$ - in Gyalrong and Tibetan etyma, see Jacques (2015a).

2. 敗 $p æ j H<\mathrm{B} / \mathrm{S}^{*} p^{\text {¿ }} r a[t]-\mathrm{s}$ 'to defeat', Cogtse (Situ) ke-prêt 'to break', Brag-bar (Situ) ka-prāt 'to break', Japhug prrt 'to break'. 敗 also has an anticausative form $b x j H<{ }^{*} N-p^{\uparrow} r a[t]-$ $s^{*}$ brats 'suffer defeat', cognate forms are also found in Gyalrong languages, Cogtse (Situ) ke-mbrêt 'to break', Brag-bar (Situ) kə-mbrāt 'to break', Japhug mbrrt 'to break'.

\subsection{2. 月 yue *et}

1. 八 $p \varepsilon t<B / S$ * $p^{\text {S }}$ ret 'eight', Tibetan brgjad ${ }{ }_{5} 5$ 'eight' (Schuessler 2007, 152), Cogtse (Situ) wurjat 'eight', Brag-bar (Situ) karcēt 'eight', Japhug kurcat 'eight'. The Cogtse form suggests (as in the case of 'hundred') that * $p^{\text {r }}$ ret may have come from an earlier form such as ${ }^{*} p V-r^{\varsigma} j a t$ with primary yod through loss of the vowel in the first syllable and monosyllabicization. Among Gyalrong languages, the Brag-bar and Japhug etyma have the irregular onset $r c^{-}$, for the expected correspondence would be ${ }^{*} r j->r_{f^{-}}$and ${ }^{*} r j_{-}>r_{4^{-}}$, as in Zbu və-rłêt (Gong 2018, 130). The Tibetan etymon has undergone the fortition change * $r y>$ rgy (Li 1959; Hill 2011).

\subsection{3. 月 yue *ot}

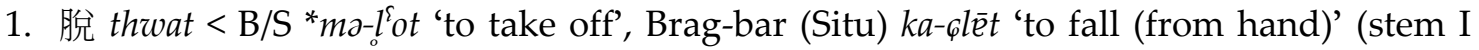
clēt, stem II $q$ lôt).

2. 刮 $k w æ t<\mathrm{B} / \mathrm{S}^{*}\left[k^{w w^{\complement}}\right] r[a] t$ 'to scrape', Cogtse (Situ) ka-khrōt 'to scratch', Brag-bar (Situ) $k a-k h r \bar{\partial} t$ 'to scratch', Japhug qhruut 'to scratch'.

3. 掘 gjut; gjwot< B/S *[g]ot; *[g]wat 'to dig out (earth)', Cogtse (Situ) ka-sakū 'to bury', Brag-bar (Situ) ka-səkū 'to bury', Japhug sku 'to bury', Tibetan $r k o$ 弟 'to dig'.

\subsection{4. 質 zhi ${ }^{*}$ it}

1. 躓/䡒 *tr-lit-s* B/S [t-l]ri[t]-s 'to slip' (Schuessler 2007, 619), Japhug asdrt 'slip'. Schuessler $(2007,619)$ also relates this word to Tibetan 'dred-pa

2. 滅 mjiet < *mit B/S *[m]et/ 'to destroy', Cogtse (Situ) ka-rmēk 'to extinguish', Brag-bar (Situ) $k \partial-m \bar{\partial} k$ 'to extinguish', Japhug $m i$ 'to extinguish'. The Japhug etymon has lost the final ${ }^{*}-k>-\gamma$ after the high vowel $i$ Jacques $(2004,224)$. The correspondence between the final $-t$ in OC and $-k$ in Gyalrong languages is unexplained.

3. 七 tshit $<\mathrm{B} / \mathrm{S}^{*}\left[t^{h}{ }^{h}\right][t]$ (possibly ${ }^{*} s-n i t$ ) 'seven'. Schuessler $(2007,419)$ relates it to 'seven' in Gyalrong languages. Cogtse (Situ) kafnās 'seven', Brag-bar (Situ) kậnēs 'seven', Japhug kuчnuz 'seven'.

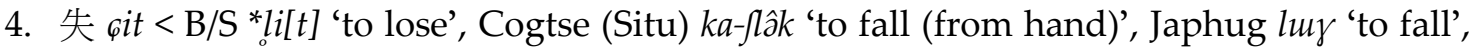
Japhug bluy 'to let sth. fall without any attention'. The Gyalrong etyma could be evidence showing that the rhyme ${ }^{*}$-it originates from ${ }^{*}-i k$ in this word (Baxter and Sagart 2014, 236). The preinitial $\varphi^{-}$is the lexicalized causative prefix. 
5. 㿎 pjijH < pits 'stiff', Japhug ndzurput 'stiff (IDEO)'6. Syllable break of the Japhug etymon is unclear between $n d z u . r p u t$ and $n d z u r . p u t$.

\section{$5.5-n /-r$ ending rhymes}

\subsection{1. 元 yuan *an/r}

The rhyme 元 *an possibly corresponds to $a$ in Gyalrong languages, but this cannot be confirmed until more cognates are found.

1. 顏 $\eta æ n<B / S{ }^{*} C . \eta^{\text {' }} r a r$ 'face' could be compared with Japhug tu-rya 'face', an etymology which would imply an alternative reconstruction *ryan in OC. Schuessler $(2007,551)$ proposes two other etymologies of this word: derivation from 御连訝 $n g j o H<{ }^{*}[\eta](r) a-s$ 'to meet' by suffixation of $-n$ nominalizer, or cognate of Tibetan $n g a r$ $5 x$ 'front side'.

$$
\text { 5.5.2. 元 }{ }^{*} e n / r
$$

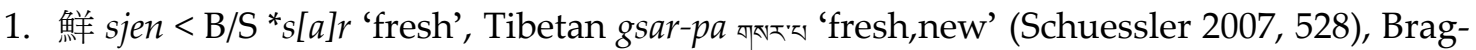
bar (Situ) kə-tsâr 'fresh', Japhug srr 'fresh'.

$$
\text { 5.5.3. 元 }{ }^{*} \text { on } / r
$$

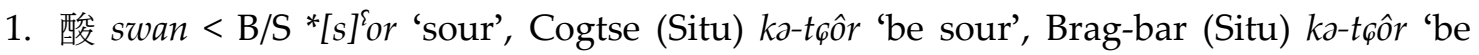
sour', Japhug ţur 'be sour'

2. 晚 $m$ jon $X<\mathrm{B} / \mathrm{S}^{*} m[o][r] 2$ 'late', Cogtse (Situ) tə-mōr 'night', Brag-bar (Situ) ta-mēr 'night' $<{ }^{*}$ ta-mōr, Brag-bar (Situ) rə-môr 'one night', Japhug tu-rmur 'night'. The $\gamma$ - preinitial in Japhug etymon comes from wrong segmentation from the numeral prefix 'one', as is the case in Japhug tw-xpa 'one year' (Jacques 2017b).

\subsection{4. 文 wen * $\partial n / r$}

1. 蚓 jinX $<\mathrm{B} / \mathrm{S}^{*}[\mathrm{G}](r) \partial[r] 2$ 'earthworm' (Schuessler 2007, 574), Japhug qa-ndze 'earthworm', Tibetan srin ब्रेव 'worm'. Japhug -ndze comes from Proto *nre- (Jacques 2004, 295).

\subsection{5. 文 wen *un/r}

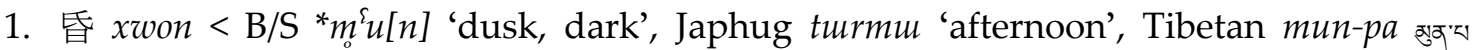
'darkness', Tibetan mun-po खुव ‘خ 'dark'.

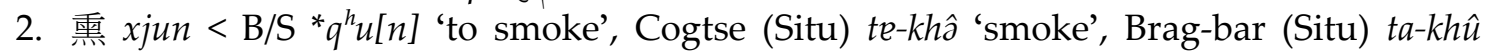
'smoke', Japhug tr-khw 'smoke'.

\section{6. $-p$ ending rhymes}

\subsection{1. 緝 ji * $\partial p$ *ip}

1. 立 lip < B/S *k.rap 'to stand', Cogtse (Situ) ka-rjāp 'to stand', Brag-bar (Situ) ka-rjēp 'to stand'.

\footnotetext{
${ }^{6}$ Etymology suggested by Gong Xun.
} 
2. 波 kip < kәp 'to scoop water', Brag-bar (Situ) ka-kiēp 'to carry water on back', Japhug kaß 'to carry water on back'. Brag-bar (Situ) sa-kāp 'well', Japhug sakaß 'well' are lexicalized locative participles, formed by adding the oblique participant nominalizer $s V$ - (Sun 2006; Jacques 2016c).

$5.7-m$ ending rhymes

$$
\text { 5.7.1. 侵 qin * } \partial m^{*} u m
$$

1. 領 $\operatorname{romX}<\mathrm{B} / \mathrm{S}{ }^{*}[\mathrm{G}]^{\mathrm{S}}[\mathrm{a}] m$ 2 'jaw, chin', Japhug ta-mGom 'pliers'.

2. 枕 $\operatorname{t}$ imX $<\mathrm{B} / \mathrm{S}^{*}[t . k][\partial] m 2$ 'pillow', Brag-bar (Situ) ta-mkâm 'pillow', Japhug tr-mkum 'pillow'. The $t$ - preinitial in OC could be related to the indefinite possessive prefix in Gyalrong languages.

3. 三 sam < * sam B/S *s.rum 'three', Tibetan gsum শतुুब 'three' (Schuessler 2007, 449), Cogtse (Situ) kasâm 'three', Brag-bar (Situ) kasâm 'three', Japhug xsum 'three'.

4. 參 sim < ${ }^{*}$ sram B/S *s.rum 'plant root', Cogtse (Situ) te-srêm 'root', Brag-bar (Situ) ta-srâm 'root', Japhug tr-zrrm 'root' (Jacques 2015a).

5. 覃 dom <*£lam B/S *N.r[o]m 'to extend, spread', Brag-bar (Situ) rə-kcâm 'length of two

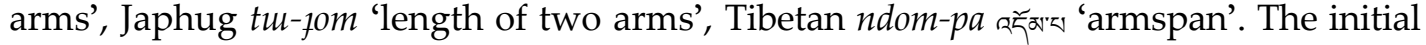
consonant $f^{-}$of the Japhug etymon may have come from the Proto ${ }^{*} j-$, and $n d$ - in the Tibetan etymon from ${ }^{*} n l$ - (Jacques 2004, 148). The preinitial $k$ - in the Brag-bar etymon remains unexplained.

6. 針 $t_{\text {tim }}<\mathrm{B} / \mathrm{S}^{*}$ t.[k]am 'needle', Cogtse (Situ) ta-kāp 'needle', Brag-bar (Situ) ta-wiē $p$ 'needle', Japhug ta-qaß 'needle', Tibetan $k h a b$ 'needle'. The preinitial *t-in OC could be related to the indefinite possessive in Gyalrong languages. The $w$-initial in Brag-bar etymon is due the ${ }^{*} k->w$ - lenition.

7. 陰 $\operatorname{Rim}<\mathrm{B} / \mathrm{S}^{*} q(r) u m$ 'be cloudy, dark', Brag-bar (Situ) ta-ncâp 'dark side of the mountain', Japhug Nqiaß 'dark side of the mountain'. The consonant cluster with a uvular initial and $-j$ - medial in Northern Gyalrong languages corresponds to the palatal initial in Situ, Proto-Gyalrong *uvular-j- has been palatalized in Situ Jacques $(2004,309)$.

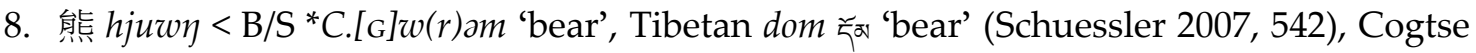
(Situ) tawām 'bear', Brag-bar (Situ) tawām 'bear'. The Tibetan etymon comes from *dwam, *wa could have been monophthongized to $o$ (Jacques 2009) as in Japhug *wa $>$ Gja 'tooth' and Tibetan *swa > so * 'tooth'.

\section{8. $-w$ ending rhymes}

Gyalrong languages lack $-w$ coda in native words.

\subsection{1. 幽 you *iw}

The rhyme 幽 *iw corresponds to a non-front vowel in Gyalrong languages, a in Cogtse (Situ), $u$ in Brag-bar (Situ) and $u$ in Japhug.

1. 梟 kew < * ‘kiw 'owl' (Schuessler 2007, 535), Cogtse (Situ) pka-khā 'owl', Brag-bar (Situ)

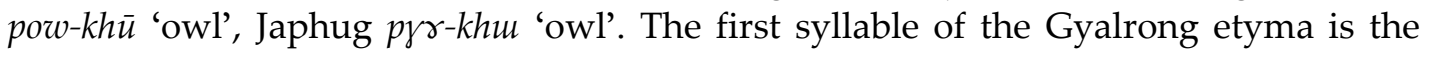

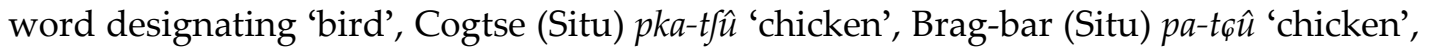
Japhug prr-tøu 'bird'. 


\subsection{2. 宵 xiao *aw}

1. 謷 $\eta a w<B / S^{*} \eta^{\uparrow} a w$ 'to fry, roast', Tibetan $r n g o ¥$ 'to fry' (Schuessler 2007, 151), Cogtse

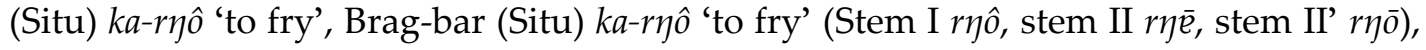
Japhug ryu 'to fry'. The Gyalrong forms could also be loanwords from Tibetan.

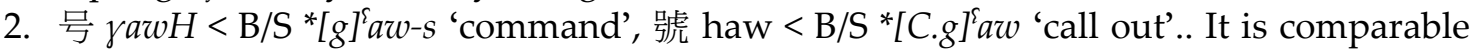

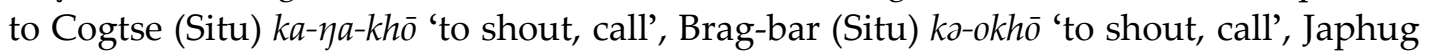
$a k h u$ 'to shout, call'.

\section{9. $-j$ ending rhymes}

\subsection{1. 歌 ge * $a j$}

1. 罢 $p j e<\mathrm{B} / \mathrm{S}$ * praj 'brown-and-white bear', Cogtse (Situ) prī 'Asiatic brown bear', Bragbar (Situ) prī 'Asiatic brown bear', Japhug pri 'Asiatic brown bear'.

\subsection{2. 脂 $\mathrm{zhi}{ }^{*} i j$}

1. 屎 $6 i j X<\mathrm{B} / \mathrm{S}^{*}\left[q^{h}\right] i j 2$ 'excrement', Japhug tu-qe 'excrement'. An alternative reconstruction *lhij? is proposed by Schuessler $(2007,465)$, it is comparable to Tibetan lci-ba ঔे ' 'excrement' < PT *lhyi, and Japhug tu- $\gamma l i$ 'excrement' < Proto-Gyalrong *klij (Jacques 2004, 313).

2. 米 $m e j X<{ }^{*} m i j z \mathrm{~B} / \mathrm{S} *(\mathrm{C}$. $) m^{\S}[e] j 2$ 'millet or rice grains', smai-khrī “小米” (Huáng and Sūn $2002,550)$. The second element of this etymon is the widespread word of 'rice' in Situ, Cogtse (Situ) khrī 'rice', Brag-bar (Situ) khrī 'rice', also found in Japhug khru-zwa 'cooked rice'. This word is related to Tibetan khre ' 'millet'.

3. 矢 B/S ${ }_{0}^{*} i[j]$ ' 'arrow', Japhug tw-di 'arrow'. The voice initial consonant $d$ - in Japhug might come from *ld- in Proto-Gyalrong (Jacques 2004, 313).

4. 死 $s i j X<B / S$ *sijz 'to die', Tibetan shi a 'to die' (Schuessler 2007, 478), Cogtse (Situ) ka-fi 'to die', Brag-bar (Situ) $k \partial-G \hat{\imath}$ 'to die', Japhug si 'to die',

5. 妣 pjijX < B/S *piji-s 'deceased mother', Schuessler $(2007,162)$ relates this word to Tibetan phyi-mo इ્के ' 'grandmother', which according to Benedict (1942) is the common Tibeto-Burman root for grandmother. The Gyalrong words Cogtse (Situ) ta-wî 'grandmother', Brag-bar (Situ) ta-wî 'grandmother', Japhug $t \gamma-w i$ 'grandmother' are possible cognates.

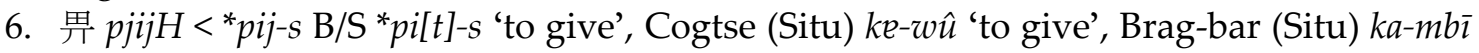
'to give', Japhug $m b i$ 'to give', Tibetan sbyin 종ㅎㅁ 'to confer'. The initial consonant of the Cogtse etymon presents ${ }^{*} b->w$ - lenition.

7. 二 $n i j H<\mathrm{B} / \mathrm{S}$ *nilj]-s 'two', Tibetan gnyis गु़े 'two' (Schuessler 2007, 226-27), Cogtse (Situ) kanês 'two', Brag-bar (Situ) kanâs 'two', Japhug вnuz 'two'.

\subsection{3. 微 wei ${ }^{*} a j$}

The rhyme 微 * ${ }^{*}$ * $u j$ corresponds to a high/mid-high vowel in Gyalrong languages, i/e in Cogtse (Situ), i/e/ej in Brag-bar (Situ) and i/e in Japhug.

1. 眉 $m i j<{ }^{*} m r a j \mathrm{~B} / \mathrm{S}$ *mr[a][r] 'eyebrow' (Schuessler 2007, 377), Cogtse (Situ) ta-rpê 'hair', Brag-bar (Situ) ta-rnê 'hair', Japhug tr-rme 'hair'. This root is also found in compound nouns Brag-bar (Situ) ta-we-rnê 'hair', Japhug tu-kr-rme 'hair', the first syllable is the constructed status of Brag-bar (Situ) ta-wô 'head', Japhug tu- $k u$ 'head'. 


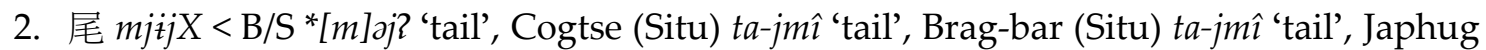
tr-jme 'tail'. The $j-(j m-)$ preinitial in the Gyalrong etyma comes from the ${ }^{*} l-\left({ }^{*} l m-\right)$ preinitial before labial initials (Jacques 2004, 271), which has no equivalent in OC.

3. 雨 nyeX < B/S *n[a][r]? 'near'. Schuessler $(2007,226)$ relates this word to Tibetan nye-ba

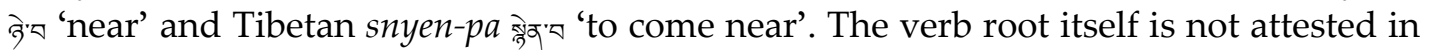
Gyalrong languages, but the noun Japhug tu- $\mathrm{kni}$ 'friend' is a possible cognate of Tibetan gnyen गबेन 'friend, relative', a noun derived from the verb root by the $g-\ldots-n$ circumfix (Jacques 2018).

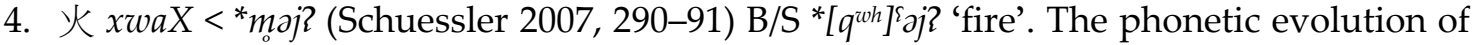
this word from OC is irregular, as MC -wa normally comes from OC ${ }^{*}-a j$ or ${ }^{*}-o j$. The word 火 rhymes as *-aj in the Shijing, as in 七月流火, 九月授衣 (《㨡風 - 七月»). Schuessler (2007, 290-91) relates this word to Tibetan me əे 'fire' (see also Hill 2013 on an alleged spelling of this word in Tibetan cited by some Sinologists). Cognate is found in Japhug smi 'fire'. This word could originally be a compound *su-mi, in which $s w$ is the construct status of Japhug si 'firewood', and cannot be used as evidence for a cluster ${ }^{*}$ sm- in Old Chinese.

\subsection{4. 微 wei * $u j$}

1. 虺 $x$ wojX <*^hmaj? B/S *[r]u[j]? 'snake brood; sound of thunder' (Schuessler 2007, 287), Cogtse (Situ) kha-brē 'snake', Brag-bar (Situ) kha-prēj 'snake', Japhug qa-pri 'snake', Tibetan sbrul 정먼 'snake' <*smrul (Jacques 2004, 137). There is no equivalent of $s$ - preinitial of the Tibetan etymon in OC and Gyalrong languages. The Gyalrong etymon for 'snake' could also be possible cognate of 巴 pæ< ${ }^{*} p^{\text {r }} r a$ 'snake'.

\subsection{Wanderwörter}

1. 菽7 syuwk < B/S * ${ }^{*}-t\left({ }^{h}\right) u k$ 'pulse, beans', Cogtse (Situ) te-stōk 'broad bean', Brag-bar (Situ) ta-stēk 'broad bean', Japhug stов 'broad bean'. The Brag-bar etymon has undergone the ${ }^{*} O>p$ sound change. Despite the regular phonetic correspondence between OC and Gyalrong words, (Sagart 1999, 185-88) points out that the bean has been domesticated too recently to be a cognate.

2. 馬 $m æ X<\mathrm{B} / \mathrm{S}^{*} m^{\complement} r a ?$ 'horse', Cogtse (Situ) mbrō 'horse', Brag-bar (Situ) mbrō 'horse', Japhug mbro 'horse'. Sagart $(1999,196)$ suggests that 馬 could be an early loanword from TB, after the loss of vowel nasalization of ${ }^{*} m r a \eta$ or ${ }^{*} m r \tilde{a}$ (also mentioned in Schuessler 2007, 373).

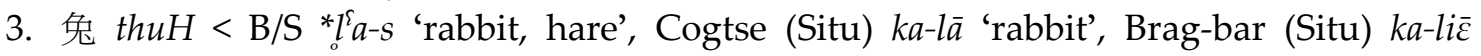
'rabbit', Japhug qa-la 'rabbit' (Schuessler 2007, 502). The first syllable in Gyalrong etyma is the lexicalized nominal prefix designating animals (Jacques 2008, 52-54).

\section{References}

Baxter, William H. 1992. A Handbook of Old Chinese Phonology. Berlin: Mouton De Gruyter.

Baxter, William H., Laurent Sagart. 2014. Old Chinese: A New Reconstruction. Oxford University Press.

Benedict, Paul K. 1942. Tibetan and Chinese Kinship Terms. Harvard Journal of Asiatic Studies 6 (3/4): 313-37.

7 These Wanderwörter have related words in many other branches of ST/TH and beyond, and a full examination of the complete dataset is beyond the scope of this work. 
Bodman, Nicholas C. 1969. Tibetan Sdud 'Folds of a Garment', the Character 卒, and the *st-Hypothesis. The Bulletin of the Institute of History and Philology 39: 327-46.

Burrow, Thomas. 1972. A Reconsideration of Fortunatov's Law. Bulletin of the School of Oriental and African Studies 35 (3): 531-45.

Coblin, Weldon South. 1986. A Sinologist's Handlist of Sino-Tibetan Lexical Comparisons. Steyler Verlag.

Conrady, August. 1896. Eine indochinesische Causativ-Denominativ-Bildung und ihr Zusammenhang mit den Tonaccenten. Leipzig: Otto Harrassowitz.

Davids, Irene Maria Hendrina, George van Driem. 1985. Limbu Kinship Terminology: A Description. Himalayan Languages XII (1-2): 115-56.

Dixon, R. M. W., Alexandra Y. Aikhenvald (eds.). 2000. Changing Valency. Cambridge University Press.

Gong, Hwang-cherng. 1995. The System of Finals in Proto-Sino-Tibetan. In: William S.-Y. Wang (ed.). The Ancestry of Chinese: 41-92. Journal of Chinese Linguistics Monograph Series.

Gong, Xun. 2017. Jiarong yuzu yuyan yu shanggu hanyu de xingtaixue (嘉线语组语言与上古汉语的形态学). In: Haeree Park, Shaoxuan Cheng (eds.). Gu wenzi yu hanyu lishi yinyunxue (古文字与汉语历史音韵学): 134-56. Shanghai: Fudan daxue chubanshe (复旦中华文明研究专刊).

Gong, Xun. 2018. Le rgyalrong zbu, une langue tibéto-birmane de Chine du Sud-ouest. Une étude descriptive, typologique et comparative. PhD thesis: Institut National des langues et des civilisations orientales.

Handel, Zev. 2002. Rethinking the Medials of Old Chinese: Where Are the R's? Cahier de Linguistique Asie Orientale 31 (1): 3-32.

Haspelmath, Martin. 1993. More on the Typology of Inchoative/Causative Verb Alternations. In: Bernard Comrie, Maria Polinsky (eds.). Causatives and Transitivity: 80-120. Amsterdam: John Benjamins.

Hill, Nathan. 2011. An Inventory Of Tibetan Sound Laws. Journal of the Royal Asiatic Society 21 (4): 441-57.

Hill, Nathan. 2013. Old Chinese *Sm- and the Old Tibetan Word for Fire. Cahier de Linguistique Asie Orientale 42 (1): 60-71.

Huáng, Liángróng, Hóngkāi Sūn. 2002. Han Jiarong cidian (漢嘉戎詞典). Beijing: Minzu chubanshe.

Jacques, Guillaume. 2004. Phonologie et Morphologie du Japhug (rGyalrong). PhD thesis, Paris: Université Paris VII Denis Diderot.

Jacques, Guillaume. 2005. Jiarongyu yu shanggu hanyu (嘉线语与上古汉语). Hanyu shangguyin guoji yantaohui (汉语上古音国际研讨会): December 2005. Ms., available online at: https://halshs.archives-ouvertes.fr/halshs00137451/document.

Jacques, Guillaume. 2008. Jiarongyu yanjiu (嘉线语研究). Beijing: Nationalities Press.

Jacques, Guillaume. 2009. Tibetan Wa-Zur and Laufer's Law. Linguistics of the Tibeto-Burman Area 32 (1): 141-44.

Jacques, Guillaume. 2012. The Tangut Kinship System in Qiangic Perspective. In: Nathan W. Hill (ed.). Medieval Tibeto-Burman Languages: 211-256. Leiden: Brill.

Jacques, Guillaume. 2013. On Pre-Tibetan Semi-Vowels. Bulletin of the School of Oriental and African Studies 76 (2): 289-300.

Jacques, Guillaume. 2015a. On the Cluster *Sr- in Sino-Tibetan. Journal of Chinese Linguistics 43 (1): 215-23.

Jacques, Guillaume. 2015b. The Origin of the Causative Prefix in Rgyalrong Languages and Its Implication for Proto-Sino-Tibetan Reconstruction. Folia Linguistica Historica 36: 165-98.

Jacques, Guillaume. 2015c. The Spontaneous-Autobenefactive Prefix in Japhug Rgyalrong. Linguistics of the TibetoBurman Area 38 (2): 271-91.

Jacques, Guillaume. 2016a. How Many *-S Suffixes in Old Chinese? Bulletin of Chinese Linguistics 9 (2): $205-17$.

Jacques, Guillaume. 2016b. Le Sino-Tibétain: Polysynthétique Ou Isolant? Faits de Langues 47 (1): 61-74.

Jacques, Guillaume. 2016c. Subjects, Objects and Relativization in Japhug. Journal of Chinese Linguistics 44 (1): 1-28.

Jacques, Guillaume. 2017a. La Nasale Intrusive En Limbou. Panchronica (available online at:. https://panchr.hypotheses.org/1654).

Jacques, Guillaume. 2017b. The Morphology of Numerals and Classifiers in Japhug. In: Picus Sizhi Ding, Jamin Pelkey (eds.). Sociohistorical Linguistics in Southeast Asia: 135-48. Leiden: Brill.

Jacques, Guillaume. 2018. Fossil Nominalization Prefixes in Tibetan and Chinese. In: LFK Society Young Scholar Symposium. Taipei.

Kümmel, Martin J. 2007. Konsonantenwandel: Bausteine zu einer Typologie des Lautwandels und ihre Konsequenzen für die vergleichende Rekonstruktio. Wiesbaden: Dr. Ludwig Reichert Verlag.

Lai, Yunfan. 2017. Grammaire Du Khroskyabs de Wobzi. PhD thesis, Université Sorbonne Nouvelle - Paris 3.

Li, Fang-Kuei. 1959. Tibetan Glo-Ba-'Dring. In: Søren Egerod, Else Glahn (eds.). Studia Serica Bernhard Karlgren Dedicata: 55-59. Copenhagen: Ejnar Munksgaard. 
List, Johann-Mattis. 2016. Beyond Cognacy: Historical Relations Between Words and Their Implication for Phylogenetic Reconstruction. Journal of Language Evolution 1 (2): 119-36.

Miyake, Marc Hideo. 2012. Complexity from Compression: A Sketch of Pre-Tangut. In: Irina Popova (ed.). Tanguts in Central Asia: A Collection of Articles Marking the 80th Anniversary of Prof. E. I. Kychanov: 244-61. Moscow: Vostochnaja Literatura.

Nagano, Sadako. 1994. A Note on the Tibetan Kin Terms Khu and Zhang. Linguistics of the Tibeto-Burman Area 17 (2): 103-15.

Peiros, Ilia, Sergei Starostin. 1996. A Comparative Vocabulary of Five Sino-Tibetan Languages. Melbourne: University of Melbourne, Department of Linguistics.

Prins, Marielle. 2016. A Grammar of RGyalrong Jiăomùzú (Kyom-Kyo) Dialects. Leiden: Universiteit Leiden.

Pulleyblank, Edwin G. 1981. Some Notes on Chinese Historical Phonology. Bulletin de L'École Française d'ExtrêmeOrient 69: 277-88.

Pulleyblank, Edwin G. 2000. Morphology in Old Chinese. Journal of Chinese Linguistics 28 (1): $26-51$.

Sagart, Laurent. 1999. The Roots of Old Chinese. John Benjamins Publishing Company.

Sagart, Laurent. 2017. A Candidate for a Tibeto-Burman Innovation. Cahiers de Linguistique Asie Orientale 46: 101-119.

Sagart, Laurent, William H. Baxter. 2012. Reconstructing the *S- Prefix in Old Chinese. Language and Linguistics 13

(1): 29-59.

Sagart, Laurent, Guillaume Jacques, Yunfan Lai, Robin J. Ryder, Valentin Thouzeau, Simon J. Greenhill, JohannMattis List. 2019. Dated Language Phylogenies Shed Light on the Ancestry of Sino-Tibetan. Proceedings of the National Academy of Sciences of the United States of America 116 (21): 10317-22.

Schuessler, Axel. 2007. ABC Etymological Dictionary of Old Chinese. Honolulu: University of Hawai'i Press.

Simon, Walter. 1929. Tibetisch-Chinesische Wortgleichungen, ein Versuch. Mitteilungen des Seminars für Orientalische Sprachen an der Friedrich-Wilhelms-Universität zu Berlin 32: 157-228.

Starostin, Sergei A. 1989. Rekonstrukcija Drevnekitajskoj Fonologičeskoj Sistemy [Reconstruction of the Phonological System of Old Chinese]. Moscow: Nauka.

Sun, Jackson T.-S. 2006. Caodeng jiarongyu de guanxiju (草登嘉戎語的關係句). Language and Linguistics 7 (4): $905-33$.

Sun, Jackson T.-S, Youjing Lin. 2007. Constructional variation in rGyalrong relativization: how to make a choice?

In: Pre-Conference Proceedings of the International Workshop on Relative Clauses: 205-226. Taipei: Institute of Linguistics, Academia Sinica.

Zhang, Shuya. 2016. La morphologie et la phonologie du dialecte de Brag-dbar du rgyalrong situ. Master's thesis: Institut National des langues et des civilisations orientales.

Zhang, Shuya. 2018. Stem Alternations in the Brag-bar Dialect of Situ Rgyalrong. Linguistics of the Tibeto-Burman Area 41 (2): 294-330.

Чжан Шуя, Гийом Жак, Аай Юньфань. К вопросу о когнатах между гьярунгскими языками и древнекитайским

Гьярунгские языки, составляющие подгруппу бирмано-цянской ветви сино-тибетской семьи, распространены на западе китайской провинции Сычуань. Они относятся к полисинтетическому типу и обладают богатыми системами глагольной морфологии. Хотя гьярунгские языки не демонстрируют близкого родства с китайским языком, они, тем не менее, представляют большой интерес для сравнительного изучения синотибетских (транс-гималайских) языков из-за архаичной природы их фонологической и морфологической систем. В данной статье, опираясь на предшествующие исследования в области древнекитайской фонологии и сопоставляя их с результатами новейших полевых данных, мы пытаемся показать, каким образом гьярунгские языки могут пролить свет на особенности древнекитайской морфологии и помочь тем самым скорректировать реконструкцию древнекитайского языка. В статье также приводится список возможных когнатов между древнекитайским и гьярунгскими языками, включая тибетские параллели там, где они обнаруживаются.

Ключевые слова: гьярунгские языки, древнекитайский язык, этимологические когнаты, сравнительная морфология, историческая реконструкция. 